\title{
Dural Plasmacytoma Mimicking Meningioma
}

\section{Menenjiyomu Taklit Eden Dural Plazmositom}

\author{
Negar AZARPIRA ${ }^{1}$, Puria NOSHADI², Sara PAKBAZ ${ }^{2}$, Simin TORABINEGHAD ${ }^{2}$, Mohamad RAKEI ${ }^{3}$, \\ Akbar SAFAI ${ }^{2}$ \\ ${ }^{1}$ Transplant Research Center, Department of Pathology, Shiraz, Iran \\ ${ }^{2}$ Ministry of Health, Shiraz University of Medical Sciences, Department of Pathology, Shiraz, Iran \\ ${ }^{3}$ Ministry of Health, Shiraz University of Medical Sciences, Department of Neurosurgey, Shiraz, Iran
}

Corresponding Author: Negar AZARPIRA / E-mail: negarazarpira@yahoo.com

\begin{abstract}
Plasma cell tumors are characterized by a monoclonal proliferation of immunoglobulin-secreting plasma cells. Dural infiltration of plasma cells without involvement of the parenchyma, leptomeninges or skull is a rare event. We present a 34-year-old man presenting with hallucination and amnesia. Magnetic resonance imaging revealed a left fronto-temporal mass with a dural tail mimicking meningioma. The mass was excised and histopathological examination revealed sheet of mature plasma cells. The cells were immunoreactive for kappa light chain, MUM1, CD38, and negative for epithelial membrane antigen. There was no recurrence after postoperative radiotherapy. Intracranial involvement from plasmacytoma should be considered in a case of solitary dural mass.
\end{abstract}

KEYWORDS: Plasmacytoma, Brain, Dura

öz

Plazma hücresi tümörleri immünglobülin salgılayan plazma hücrelerinin monoklonal proliferasyonuyla karakterizedir. Parankim, leptomeningsler veya kafatası tutulumu olmadan plazma hücrelerinin dural infiltrasyonu nadiren görülür. Halüsinasyon ve amneziyle gelen 34 yaşında bir erkeği sunuyoruz. Manyetik rezonans görüntüleme dural kuyruğu olan ve menenjiyomu taklit eden sol frontotemporal kitleyi ortaya koydu. Kitle eksize edildi ve histopatolojik inceleme matür plazma hücreleri tabakası ortaya koydu. Hücreler kappa hafif zincir, MUM1, CD38 için immünreaktif ve epitelyal membran antijeni için negatifti. Postoperatif radyoterapiden sonra nüks olmadı. Tek başına bir dural kitle varlığında bunun plazmositomun intrakranial yayılımı olabileceği göz önünde bulundurulmalıdır.

ANAHTAR SÖZCÜKLER: Plazmositom, Beyin, Dura

\section{INTRODUCTION}

Plasma cell tumors are characterized by a monoclonal proliferation of plasma cells. Plasmacytoma may arise from osseous (intramedullary) or non-osseous (extramedullary) sites, may be solitary or multiple, and may be associated with or may progress to multiple myeloma. Intracranial plasmacytoma can arise from the cranium, meninges or brain parenchyma $(7,9)$. Diffuse leptomeningeal and/ or parenchymal involvement are seen in multiple myeloma. Dural infiltration without skull or brain parenchyma involvement is an extremely rare event $(1,4,5)$. The differential diagnosis of plasmacytoma in dura mater includes meningioma, which has a similar MRI appearance, metastasis and lymphoma of the dura mater. Meningioma is the most common primary nonglial brain tumor with typical radiological features: an extraaxial tumor with broad attachment to the dura, hyperdense on computerized tomography (CT), isointense with grey matter on T1-weighted MRI with enhancing 'dural tail' $(1,5,6)$.

\section{CASE REPORT}

In October 2011, a 34-year-old man presented at our Neurosurgery Department with a 6-month history of hallucination and amnesia. On magnetic resonance imaging (MRI), an extra-parenchymal mass in the left fronto-temporal region with a broad dural base was revealed, strongly suggestive of a meningioma. It was a solitary lesion without associated lytic lesions in the skull (Figure 1). He underwent surgery via a left frontal craniotomy and the tumor was excised.

On histological examination, the cellular tumor was composed of mature plasma cells with eccentric nuclei, a paranuclear clear area and coarse chromatin was mixed with immature plasma cells. The immature plasma cells exhibited binucleation and large nucleoli.

Typical histological features of meningioma such as whorls or nuclear pseudo inclusions wereabsent (Figure 2A,B).Therefore, rhabdoid meningioma vs. plasmacytoma was considered in the differential diagnosis. The cells were positive for CD38 (Figure 3) and MUM1 and expressed kappa light chain, but were negative for lambda light chain, epithelial membrane antigen (EMA), cytokeratin, vimentin and myeloperoxidase (MPO), (DAKO, Denmark). These findings are indicative of neoplastic plasma cells. CD38 and MUM1 are markers of neoplastic plasma cells. EMA is considered as an arachnoidal cels marker, 


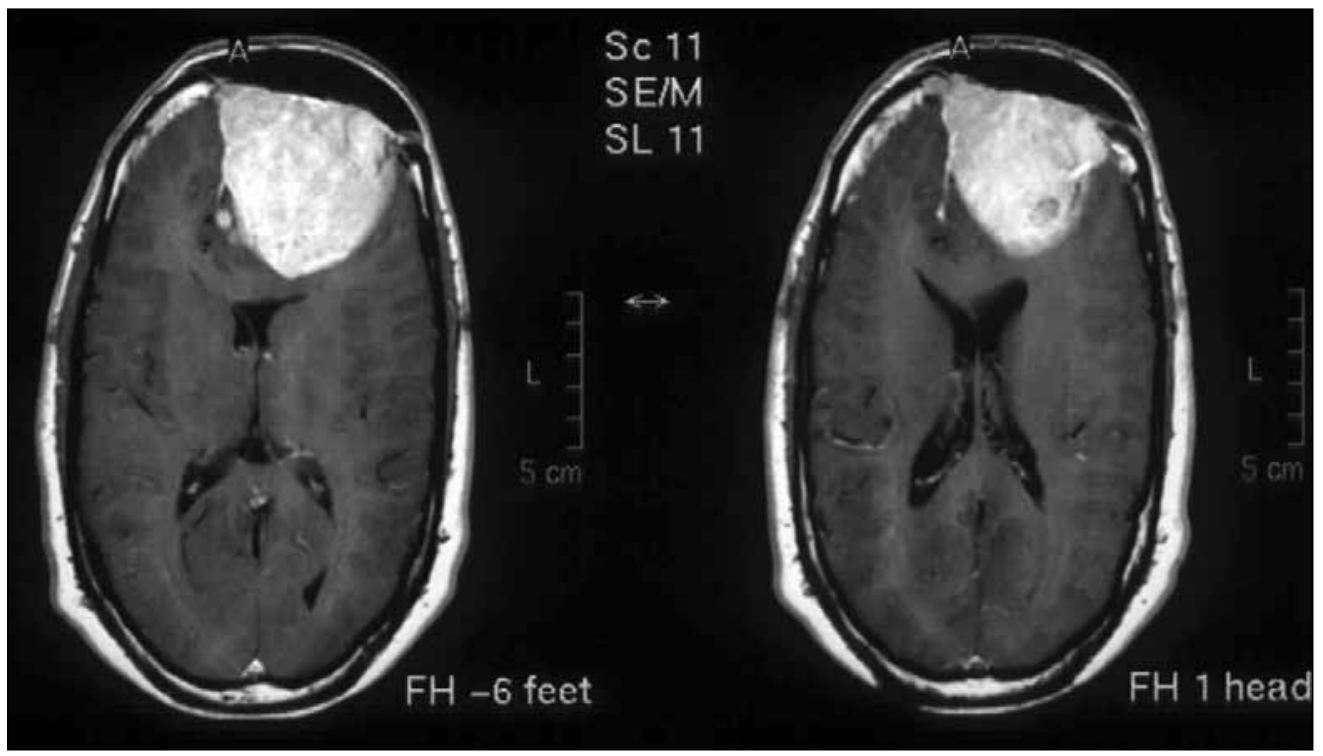

Figure 1: Axial T1-weighted MRI shows a solid mass in the left frontal region with contrast enhancement with a 'dural tail'.
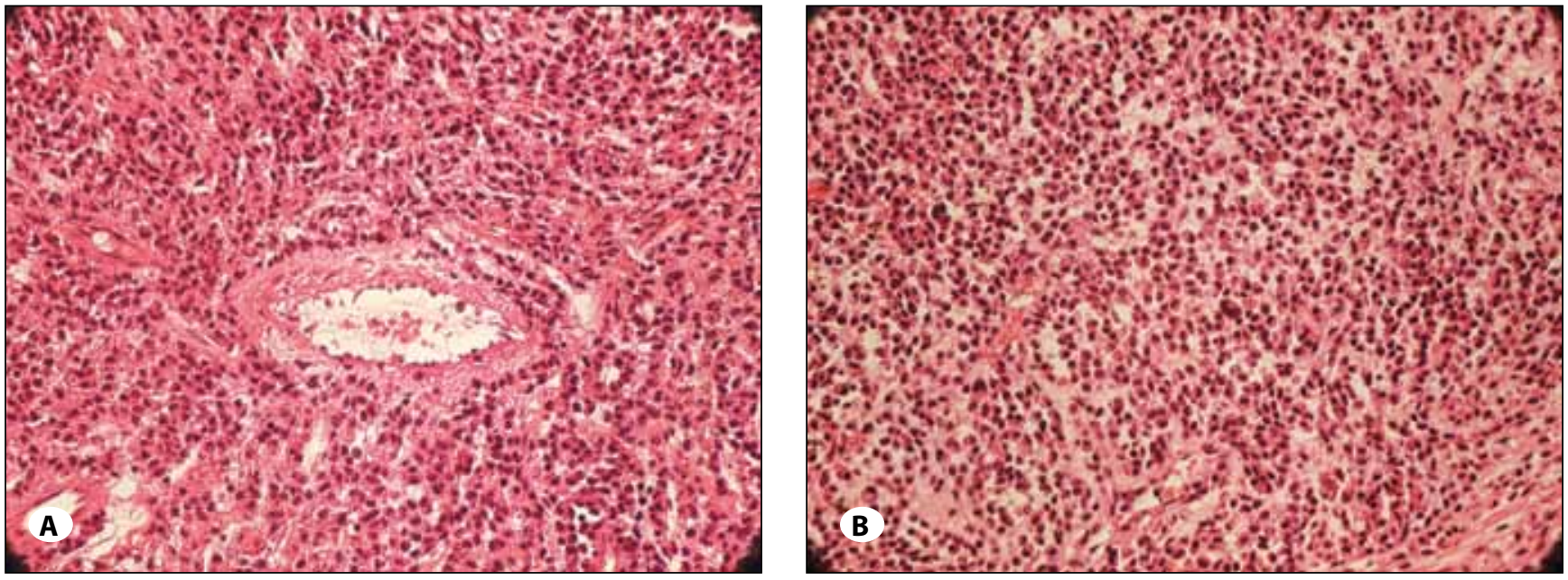

Figure 2: Pathological examination of the surgical specimen showing a sheet of plasma cells (H\&E stain $\times 100)$.

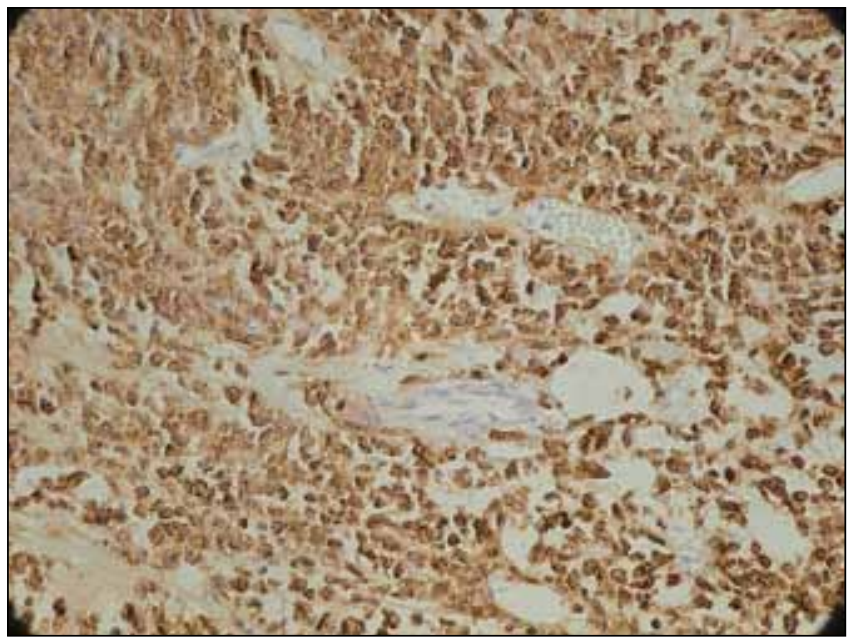

Figure 3: Immunohistochemical staining of CD38 $(\times 100)$. expressed by most meningiomas in diffuse fashion. After the diagnosis of meningeal plasmacytoma, a systematic work up to rule out multiple myeloma was performed. No additional sites of tumoral lesion were identified on either computed tomography or bone scan. Bone marrow aspiration and biopsy showed a normocellular marrow. Serum immunoglobulin levels were normal (IgG 1,28 mg/dL, IgA 397 mg/dL, IgM 52g/ $\mathrm{dL}$, and $\mathrm{lg} E 79 \mathrm{IU} / \mathrm{mL}$ ). Serum protein immunoelectrophoresis showed a normal pattern. Urine Bence-Jones protein was negative. Hypercalcemia was not detected. Thus, a diagnosis of extramedullary plasmacytoma was made. He underwent local external beam radiotherapy at a dose of $50 \mathrm{~Gy}$, which resulted in the disappearance of the remaining tumor and there has been no recurrence.

\section{DISCUSSION}

Plasma cell neoplasms are characterized by clonal neoplastic proliferation of plasma cells, producing a monoclonal 
immunoglobulin. Primary extramedullary plasmacytomas are uncommon tumors, mainly arising in the head and neck region, particularly the upper aerodigestive tract. Conversion to multiple myeloma more frequently occurs in intramedullary plasmacytoma. Overall, cranial and intracranial plasmacytoma may involve the cranial vault and the skull base or the brain parenchyma. However, intracranial involvement in plasmacytoma is uncommon $(9,10)$.

Cerase et al., reviewed the clinical features and neuroradiological findings of seven patients diagnosed as plasmacytoma and multiple myeloma with intracranial growth (3). They believed that intracranial involvement in multiple myeloma generally results from extramedullary tumor masses arising from bone lesions in the calvaria, skull base, and nasal or paranasal sinuses. Dural involvement usually resulted from direct spread of contiguous bone lesions. Leptomeningeal spread of multiple myeloma was also occurred by hematogenous rout as focal, multifocal or diffuse forms (3). Sahin et al., reported a case of dural plasmacytoma in a patient with multiple myeloma, who presented with headache four years after complete remission of disease (8). Manabe et al., described a 59-yearold man presented with history of amnesia. The temporal mass was plasmacytoma and no additional sites were identified. The patient underwent external beam radiotherapy to the brain at a dosage of $50 \mathrm{~Gy}$, which resulted in complete disappearance of the mass (6). Vujovic el al., reported another case of intracranial plasmacytoma arising from the meninges, which was treated with surgery and radiotherapy (11).

Solitary dural plasmacytoma is rare and mostly occurs in the fifth decade of life with female predominance. Increased intracranial pressure and seizure are the usual clinical presentation. There is no pathognomonic radiologic feature. The differential diagnosis in such cases includes meningioma and metastasis. On CT scan, an intracranial plasmacytom usually presents as a dense tumor with enhancement after intravenous contrast administration. A sharp tumor border with lack of bony sclerosis is suggestive of solitary plasmacytoma. Metastatic tumors (most commonly from thyroid, renal, or bronchial cancers) are usually lytic lesions $(3,5,6)$. However, metastatic disease should be considered in all patients who experience new neurological finding, even after a prolonged disease-free interval (3).

The clinical and neuroradiological spectrum of intracranial plasmacytoma and multiple myeloma is very different. Therefore they must be taken into account in cranial osseous and dural lesions $(3,8)$. Definite distinction may be impossible and requires histopathological examination. To make the correct diagnosis, systemic multiple myeloma must be ruled out. The monoclonal nature of tumor cells must also be confirmed to rule out an inflammatory process such as plasma cell granuloma (4-6).
Cerase et al., believed that if anatomically suitable, complete surgical resection followed by radiotherapy is the treatment of choice, because the tumor is very radiosensitive. Tumors at the skull base are treated by subtotal or total resection followed by radiotherapy, or irradiation alone. Systemic therapy such as chemotherapy is recommended for refractory and/or recurrent disease $(2,10)$. Our patient was given radiotherapy and there was no tumor recurrence in the six months after diagnosis.

\section{CONCLUSION}

Intracranial plasmacytoma must be suspected in all patients with a solitary dural mass, and in the differential diagnosis of meningeal tumors.

\section{REFERENCES}

1. Benli K, Inci S: Solitary dural plasmacytoma, case report. Neurosurgery 36:1206-1209,1995

2. Bindal AK, Bindal RK, van Loveren H, Sawaya R: Management of intracranial plasmacytoma. J Neurosurg 83:218-221, 1995

3. Cerase A, Tarantino A, Gozzetti A, Muccio CF, Gennari P, Monti L, Di Blasi A, Venturi C: Intracranial involvement in plasmacytomas and multiple myeloma: A pictorial essay. Neuroradiology 50:665-674,2008

4. Gad A, Willén R, Willén $H$, Göthman L: Solitary dural plasmacytoma. Acta Pathol Microbiol Scand A 86:21-24, 1978

5. Haegelen C, Riffaud L, Bernard M, Carsin-Nicol B, Morandi $X$ : Dural plasmacytoma revealing multiple myeloma. J Neurosurg 104:608-610, 2006

6. Manabe $M$, Kanashima $H$, Yoshii $Y$, Mukai S, Sakamoto E, Iwai $\mathrm{Y}$, Kubo $\mathrm{Y}$, Fukushima $\mathrm{H}$, Inoue $\mathrm{T}$, Teshima $\mathrm{H}$ : Extramedullary plasmacytoma of the dura mimicking meningioma. Int J Hematol 91:731-732,2010

7. Mantyla R, Kinnunen J, Bohling T: Intracranial plasmacytoma: A case report. Neuroradiology 38:646-649,1996

8. Sahin F, Saydam G, Ertan Y, Calli C, Dönmez A, Tombuloglu $M$ : Dural plasmacytoma mimicking meningioma in a patient with multiple myeloma. J Clin Neurosci 13:259-261, 2006

9. Schwartz $T H$, Rhiew R, Isaacson SR, Orazi $A$, Bruce JN: Association between intracranial plasmacytoma and multiple myeloma: Clinicopathological outcome study. Neurosurgery 49:1039-1044, 2001

10. Terada T: Multiple myeloma presenting as an intracranial plasmacytoma: A case report. Cases J 2:9110,2009

11. Vujovic O, Fisher BJ, Munoz DG: Solitary intracranial plasmacytoma: Case report and review of management. J Neurooncol 39:47-50, 1998 